\title{
Accounting Fraud, And White-Collar Crimes In The United States
}

RamMohan R. Yallapragada, Fayetteville State University, USA C. William Roe, Arkansas State University, USA

Alfred G. Toma, University of Louisiana, Lafayette, USA

\begin{abstract}
Time was when fraud used to involve a simple exchange of tangible items, by the perpetrator of fraud, tricking the victims to part with something valuable and in return receive something almost worthless. In recent times, the exponential growth in communication technology and proliferation of computers paved the way for phenomenal upsurge in corporate fraud, while-collar crime, and identity theft. These crimes are costing the country hundreds of billions of dollars every year. The nation is witnessing a peculiar trend in the nature of crimes. While crimes of violence such as murder and rape and property crimes like armed robbery, burglary, and car thefts are on the decline, crimes involving accounting fraud, white-collar crime and embezzlement have shown a meteoric rise. Accounting fraud is defined as knowingly falsifying accounting records in order to boost sales revenue and net income. Accounting fraud is perpetrated by corporations by means of presenting false information, using funds for illegal purposes, overstating revenues, understating expenses, overstating the value of corporate assets, and understating liabilities. Many spectacular corporate scandals such as Enron in the past decade involved large scale accounting fraud. Corporate fraud can have devastating consequences, not just to the investors in the company's stock but also to tens of thousands of employees who invested their retirement savings in the company's $401 \mathrm{~K}$ accounts. Several laws were enacted to prevent corporate fraud with mixed results. Accounting students in this country have been receiving no training at all in the area of prevention and detection of fraud. This paper presents a short history of corporate fraud, the laws enacted to deal with the problem, and the role of codes of ethics for business firms in dealing with corporate fraud.
\end{abstract}

Keywords: Fraud; Communication Technology; Identity Theft; White-Collar Crime; Accounting Fraud; Corporate Accounting Scandals

\section{INTRODUCTION}

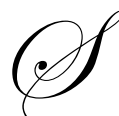

ome kind of fraud was always prevalent even in olden days in the United States. However, in those early days, fraud used to predominantly involve "a one-stop trickery" in which the cheating depended on exchanging two quite different things --- for instance, good cash for a bad check (Huber, 2004). Others sold a bottle of snake oil for a good silver dollar. Even in the remote past, there were stock market crashes of huge proportions such as the South Sea Bubble in 1722 in England and the famous New York Stock market crash in October 1929. However, these stock market crashes were caused, not by any specific fraudulent activities but, by what Greenspan later described as "irrational exuberance" of investors.

In general, most business firms conduct their operations with a high degree of integrity. Yet, in a few organizations, executives somehow succumb to pressures and opportunities to make their companies look better than what they really are, and seek to enrich themselves by resorting to illegal and unethical means (Albrecht et al., 2008). During the first decade of the $21^{\text {st }}$ century, the United States business world was shaken to its roots by a spate of corporate scandals of unprecedented proportions. Starting with Enron in 2001, several corporate scandals involving accounting manipulations came to light. Many of these scandals happened in 2002 and included a galaxy of big corporations such as Global Crossing, WorldCom, Tyco, Qwest, Adelphia, Imclone, Merrill Lynch, Smith 
Barney, Goldman Sachs, Fannie Mae, AIG and many others (Albrecht et al., 2008). Mid-term elections were approaching and the American public loudly called for legislative measures for the prevention and detection of corporate fraud. The U. S. Congress hastily enacted the notorious Sarbanes=-Oxley Act of 2002 (SOX) with far reaching consequences to U. S. business firms. Even prior to SOX, laws were enacted in the U. S. (laws such as the Securities Act of 1933, Securities Exchange Act of 1934, and Foreign Corrupt Practices Act of 1977) with strict measures against corporate fraud. The remaining sections of this paper deal with details regarding two of the biggest corporate frauds, Enron and WorldCom, the deleterious consequences thereof, the recent trend of increasing white-collar crimes in the U. S. and the anti-fraud statutes passed so far in the United States.

\section{WHITE-COLLAR CRIMES}

The phenomenal advances in the field of information technology and the pervasive use of computers in every walk of life resulted in an uncontrolled upsurge in white-collar crime in the United States. As Johnston (2002) reports, one in three American households are victims of white-collar crimes. These crimes include fraudulent activities relating to securities transactions, insurance claims, healthcare fraud, credit cards, money laundering and crimes involving computers and telecommunications. These white-collar crimes are becoming increasingly costly to the nation. According to National Fraud Center Stats, the total cost of these economic crimes to the nation was \$5 billion in 1970, $\$ 20$ billion in 1980 and $\$ 100$ billion in 1990. Also, according to the Federal Bureau of Investigation's Uniform Crime Reports, arrests during the period of 1988 thru 1999, for most violent crimes such as murder, manslaughter, and rape and property crimes such as robbery, theft etc., were on the decline whereas crimes involving fraud have shown significant upsurge during the same period (Johnston, 2002). Many of us are completely unaware of the gravity the prevalence of white-collar crime in our society, nor do we have any training to protect ourselves against these electronic crimes in this computer dominated age.

\section{RECENT CORPORATE ACCOUNTING SCANDALS}

Many of the American business firms conduct their operations and publish their financial statements following the requirements as per the US Generally Accepted Accounting Principle. United States did not become the most powerful financially successful country in the world by taking recourse to fraud. Hard work and scientific and technological innovations were the main engines that propelled the US to the status of the most prosperous nation in the world, within two hundred years of its coming into existence. However, there have always been some black sheep, corporations that tried to get ahead by illegal and unethical means. Eventually, they almost always met their doom. It is strange to note that even in these times of phenomenal technological advances we are still having some corporate accounting scandals of biblical proportions.

\section{Enron}

Among all the scandals, Enron and WorldCom are two of the largest corporate accounting scandals in the history of the American business environment. As Giroux (2008) describes, both Enron and WorldCom represent fraud on a large scale even though entirely different from each other. Enron used sophisticated methods for committing fraud based on complex financial instruments and derivatives whereas, WorldCom used brazen and unsophisticated schemes such as capitalizing operating expenses of billions of dollars. In the last decade, many corporate accounting scandals occurred mainly in two specific industries, energy and telecommunications. Enron was in the energy industry and WorldCom, in the industry of telecommunications. In many of these scandals, two main characteristics stand out prominently - - corporate greed and earnings manipulation. Enron contributed the most spectacular corporate scandal during the early years of the twenty first century. At its high point in August 2000, Enron was the seventh largest US corporation with a market capitalization of $\$ 70$ billion and reported revenues of over $\$ 100$ billion. Enron's chairman Ken Lay had a base salary of $\$ 1.3$ million. His bonus for the year was $\$ 7$ million and exercised $\$ 123$ million worth of stock options. All of this was happening while a full-scale earning manipulation was going on. Enron's stock was trading at $\$ 90$ per share in 2000. In December 2001, after the scandal was discovered, its stock price came down to less than $\$ 1$. Enron declared bankruptcy in December 2001. It was the largest bankruptcy in the history of United States until WorldCom bankruptcy came along one year later. Giroux (2008) gives a captivating description of the Enron tragedy. 
In terms of scandal, Enron had it all: gigantic executive compensation incentive packages, management dedicated to meeting all quarterly earnings forecast to maintain the compensation - - often by accounting manipulation; a rubber-stamping board of directors; a chief financial officer enriching himself through related party partnerships and hidden side agreements; an accommodating auditor in Arthur Anderson and an equally accommodation law firm in Vinson and Elkins; investment bankers who would structure virtually any financial deal anywhere in the world for big fees, and financial analysts always rating Enron as a strong buy no matter the economic reality; and a political system that often stacked the deck in favor of Enron thanks in part to large campaign contributions...there seemed to be a complete lack of ethical standards by almost everyone involved. Enron can be considered a microcosm of the entire scandal environment. In the end, Enron's chair Ken Lay was found guilty on ten counts. $H E$ died of heart attack before he was sentenced. CEO Skilling was sentenced for twenty-four years. CFO Fastow plea-bargained for a ten-year prison term. Thousands of Enron employees lost their jobs along with their hardearned retirement funds invested in Enron. Thousands more of investors in Enron lost their entire investment. (Source: Giroux, 2008)

\section{Worldcom}

The American public, infuriated by the gigantic Enron debacle in 2001, was calling for stringent legal measures against corporate fraud. Congress was making some feeble attempts at some reforms against accounting fraud. A version of the future Sarbanes-Oxley legislation was before Congress but the bill was losing steam and was expected to head towards a silent death in the sub-committees. And then came along the monumental WorldCom scandal. It was just the time for the 2002 midterm elections and American public was convinced beyond doubt that Enron scandal was not an isolated case. There was a public outcry for immediate legislative against the rampant corporate corruption. Congress hastily passed the notorious Sarbanes-Oxley Act of 2002 and President Bush lost no time in signing it into law. Without the advent of WorldCom scandal on the scene, probably there would not have been a Sarbanes-Oxley Act of 2002. In July 2002, WorldCom declared bankruptcy after an $\$ 11$ billion accounting fraud came to surface. WorldCom became the largest business failure in American history, a unique place of [dis]honor, until then occupied by Enron. In 1999, WorldCom had a market capitalization of $\$ 115$ billion (Giroux, 2008). In 1983, WorldCom chairman Bernard Ebbers, a former milkman with no formal education in business, started a long-distance discount service company along with others. He then had over seventy mergers, the biggest one being the 1998 acquisition of the $\$ 42$ billion company, MCI.

The accounting fraud perpetrated by WorldCom in 2002 involved recording nearly $\$ 4$ billion of operating expenses as capital expenditures. Further investigation revealed a fraudulent capitalization of more than $\$ 11$ billion of operating expenses. In July 2002, WorldCom filed for bankruptcy. In 2005, Ebbers was sentenced to twenty-five years in prison for the biggest corporate fraud in the country's history. Ebbers' sentence is the longest ever for a CEO who was found guilty of corporate fraud in a fortune 500 company.

\section{ANTI-FRAUD LEGISLATIONS}

\section{Foreign Corrupt Practices Act Of 1977}

Long before Sarbanes-Oxley law of 2002 was enacted, Congress passed a law dealing with the fraudulent activities of corporations involving bribery. It is the Foreign Corrupt Practices Act (FCPA) of 1977 which was enacted as a result of Lockheed's executives bribing Japanese companies in order to obtain their business. However, as Vardy (2010) states, for decades the FCPA was a sleepy statute, hardly enforced but, in the past few years, the federal government suddenly started enforcing this thirty-three-year-old law. Prior to 2000, federal prosecutions for FCPA crimes were practically non-existent. In 2004, there were three FCPA cases. In 2009, there were thirty-four FCPA prosecutions. The Department of Justice presently has over one hundred fifty ongoing FCPA investigations (Vardy, 2010). Not only there is an increase in the number of cases under the FCPA, the feds are ratcheting up the penalties for the FCPA crimes as well. Federal authorities recently imposed fines of $\$ 18$ million under the provisions of FCPA on the energy company Statoil for paying bribes in Iran (Ewing 2007). Since December 2008, a number of corporate executives were meted out long prison sentences and agreed to pay millions of dollars in settlements for FCPA violations (Richardson, 2009). 


\section{Sarbanes-Oxley Act (SOX)}

The Sarbanes-Oxley Act was hastily passed in 2002 as a knee-jerk reaction to the humungous accounting scandals perpetrated by companies such as Enron and WorldCom. SOX is a very complicated law which subjected corporations to heavy implementation expenditures. The law requires CFOs and CEOs to certify, under penalty of up to twenty years in prison and up to $\$ 5$ million in fines, that their companies' internal controls are in order and that these controls lead to accurate financial reports (Doherty, 2006). Because of the huge implementation costs and provision of stringent provisions, many companies started to delist themselves from American stock exchanges and fled to Europe exchanges, since SOX applies only to companies registered with American stock exchanges. London Stock Exchange was the biggest beneficiary of SOX.

\section{SUMMARY AND CONCLUSIONS}

Both Enron and WorldCom were the result of unbridled greed of corporate executives, utter lack of ethical standards, unscrupulous and cooperating auditors, lawyers, and bankers, lack of regulations, political favors, and useless and ineffective board of directors. Even within the short period in the twenty-first century, there were only twenty reported major corporate scandals period. It is hoped that the passage of SOX would help to mitigate the incidents of corporate fraud in future. In addition to the statues for the prevention of fraud, business schools should incorporate more training and courses dealing with forensic accounting in their curriculum. As Cliff (2006) states, forensic accounting is one of the fastest growing areas of study in American business schools and colleges. Corporations must also establish strict ethical codes of employee conduct with frequent training schedules which will felicitate a healthy corporate ethical culture.

\section{AUTHOR INFORMATION}

RamMohan R. Yallapragada is an Associate Professor of Accounting at Fayetteville State University. He obtained his PhD degree in Accounting from the University of Houston. He holds a CPA certificate from the State of Louisiana. He taught at University of Texas at San Antonio, Nicholls State University, and University of Louisiana, Lafayette before joining FSU. He has published in several journals including Journal of Business and Economic Research, International Business and Economic Research Journal, Journal of Accounting and Finance Research, and Clarion Business and Economic Review. His research areas include Cost Accounting in Healthcare, Accounting irregularities in Fannie Mae, and impact of Sarbanes-Oxley Act of 2002 on American corporations. E-mail: ryallapr@uncfsu.edu. Corresponding author.

C. William Roe received his doctorate from Mississippi State University in Management. He has authored/coauthored numerous journal articles and/or conference papers in management, marketing, healthcare administration and international business. He currently serves as Associate Dean and Director of Graduate Business Programs at Arkansas State University. He has consulted extensively with numerous public, private, for-profit, and not-forprofit organizations in the areas of strategic planning, leadership, organizational change and development and management development. E-mail: broe@astate.edu.

Alfred G. Toma holds the degrees of M.B.A. from the American University of Beirut, Lebanon and M.Sc in Marketing from Louisiana State University, Baton Rouge. He has co-authored journal articles and/or conference papers in the areas of International Business and Entrepreneurship. Prof. Toma is special assistant to the Dean, B. I. Moody College of Business Administration at University of Louisiana at Lafayette. He currently teaches courses in International Business Management, Entrepreneurship, and Human Resources Management. His extensive actual business and consultancy experience are focused in the areas of entry and operations in Middle East markets and entrepreneurial venture start-ups. E-mail: agt5159@louisiana.edu. 


\section{REFERENCES}

1. Albrecht, W. Steve, Chad Albrecht, and Conan Albrecht (2008). "Current Trends In Fraud And Its Detection," Information Security Journal: A Global Perspective, January 2008, Volume 17, Issue 1, pp. 212.

2. Cliff, Patrick (2006). "The New Film Studies? Forensic Accounting," Inc, September 2006, Volume 28, Issue 9 , p. 32.

3. Doherty, Brian (2006). "You Can Be Too Careful," Reason, January 2006, Volume 37, Issue 8, pp. 40-47.

4. Ewing, Jack and Eamon Javers (2007). "Siemens Braces For A Slap From Uncle Sam," BusinessWeek, November 26, 2007, pp. 78-79.

5. Giroux, Gary (2008). "What Went Wrong? Accounting Fraud And Lessons From The Recent Scandals," Social Research, Winter 2008, Volume 75, Issue 4, pp. 1205-1238.

6. Huber, Peter (2004). "Trading On Secrecy," Forbes, March 29, 2004, Volume 173, Issue 6, p. 64.

7. Johnston, Richard (2002). "The Battle Against White Collar Crime," USA Today Magazine, January 2002, Volume 130, Issue 2680, pp. 36-39.

8. Richardson, Eli, Ross Booher, and Taylor Phillips (2009). "It That A Crime?" Tennessee Bar Journal, April 2009, Volume 45, Issue 4, pp. 14-24.

9. Vardi, Nathan (2010). “The Bribery Law Racquet," Forbes, May 24, 2010, Volume 185, Issue 9, pp. 70 77. 
NOTES 